\title{
Methods for nurses to measure body composition
}

\author{
Jose Maria Moran ${ }^{1}$ \\ Jesus Maria Lavado-Garcia \\ Juan Diego Pedrera-Zamorano ${ }^{3}$
}

\begin{abstract}
Among the methods available for assessing body composition, traditional methods like hydrodensitometry and skin-fold measurements are well known. In this review, we focus on the impedance and interactance methods, which use systems that are usually inexpensive, easily transportable and simple to operate. We also discuss the usefulness of dual energy X-ray absorptiometry, particularly for the measurement of fat distribution. Nurses need to be skilled in the use of the equipment and familiar with the techniques.
\end{abstract}

Descriptors: Body Composition; Electric Impedance; Absorptiometry, Photon.

\footnotetext{
${ }^{1}$ Ph.D. in Biochemistry and Molecular Biology, Departamento de Enfermería, Universidad de Extremadura, Cáceres, Spain. E-mail: jmmorang@unex.es.

${ }^{2}$ RN, Ph.D. in Nursing, Departamento de Enfermería, Universidad de Extremadura, Cáceres, Spain. E-mail: jmlavado@unex.es.

${ }^{3}$ MD, Ph.D. in Medicine, Departamento de Enfermería, Universidad de Extremadura, Cáceres, Spain. E-mail: jpedrera@unex.es.
} 


\section{Métodos de enfermagem para a medição da composição corporal}

Entre os métodos disponíveis para a determinação da composição corporal, os tradicionais, como a hidrodensitometria e a avaliação de pregas corporais, são bem conhecidos. Para esta revisão, centrou-se nos métodos baseados na impedância e a interactância, caracterizados pela utilização de equipamentos econômicos, fáceis de transportar e manobrar. Também discutiu-se a utilidade da absorciometria dual de raios $\mathrm{X}$, especialmente para a determinação da distribuição da gordura corporal. É importante que o pessoal de enfermagem adquira conhecimentos sobre o uso desse equipamento, bem como que se familiarize com as técnicas descritas.

Descritores: Composição Corporal; Impedância Elétrica; Absorciometria de Fóton.

\section{Métodos en enfermería para la medición de la composición corporal}

Entre los métodos disponibles para la determinación de la composición corporal, los tradicionales como la hidrodensitometría y la valoración de pliegues corporales son bien conocidos. En esta revisión nos centramos en los métodos basados en la impedancia y en la interactancia, caracterizados por la utilización de equipos económicos, fáciles de transportar y manejar. También discutimos la utilidad de la absorciometría dual de rayos-X, particularmente para la determinación de la distribución de la grasa corporal. Es importante que el personal de enfermería adquiera competencias en el uso de estos equipamientos y también se familiarice con las técnicas descritas.

Descriptores: Composición Corporal; Impedancia Electrica; Absorciometría de Fotón.

\section{Introduction}

In the nursing profession, learning is a lifelong endeavor. Nurses are expected to pursue professional growth as long as they continue to work, to be competent in their areas of expertise, and to be up to date on the latest practices and understand the related technology. In the rapidly changing healthcare field, what nurses learn during their initial training can quickly become obsolete. New equipment and technology, procedural changes and new medical practices are some of the areas in which nurses are always required to have upto-date training and education.

The study of body composition is a rapidly expanding field. Body composition studies should be considered from the following two important vantage points: 1) body composition studies carried out for research purposes that later serve as models for practical applications, and 2) body composition studies carried out for clinical purposes in routine patient evaluation. Investigational studies generally use sophisticated and expensive measurement methods, whereas clinical studies are becoming increasingly less expensive and more widely used. In both cases, nurses should learn and apply the necessary methodological skills. These skills are the cornerstone of being a proficient nurse. This review will focus on the methods for measuring body composition that nurses use in clinical studies.

\section{Background}

\section{Compartmental models of body composition}

Compartmental models are often used to understand body composition at the molecular level. The twocompartment model can be characterized as either of the following combinations: body weight $(B W)=$ fat + fatfree body mass or BW = lipid + lipid-free body mass. The three-compartment models include $\mathrm{BW}=$ fat + water + residual (the sum of glycogen, minerals, and protein) and $\mathrm{BW}=$ fat + bone minerals + lean soft tissue. The fourcompartment model is $\mathrm{BW}=$ fat + water + minerals + residual (the sum of glycogen and proteins).

The evolution of methods for assessing body composition has been rapid, quickly progressing 
from the methods used for the study of the twocompartment model (body fat and fat-free mass), such early hydrodensitometric techniques ${ }^{(1)}$, to methods that enable studies of multi-compartment models, such as techniques for in vivo neutron activation analysis (IVNAA) (2), which makes it possible to study body composition at the atomic level. The methods that are becoming the most widely used are those that permit the study of the four-compartment model of body composition ${ }^{(3)}$, including fatty mass (FM), fat-free mass (FFM), water and minerals, and the three-compartment model, probably the most common, which measures FM, FFM (protein and minerals), and, water (by extrapolation) ${ }^{(4)}$.

Differences between methods are enormous, not only in terms of complexity but also in terms of cost. For example, several measurement methods have been developed for two-compartment models using radioactive techniques. FM is calculated by subtracting from the body weight the FFM estimated using total body water, total body nitrogen, or total whole-body ${ }^{40} \mathrm{~K}$ counting (TBK). Bioimpedance analysis (BIA), a simpler and less expensive method, satisfies the same functions; FM is calculated by subtracting the estimated FFM from the body weight. It is obvious that the complexity and cost of radioactive techniques are much greater than those of BIA, which involves a simple instrument that is easy to use, inexpensive, and easily managed(5-6).

Setting aside IVNAA, tracer and gas dilution, and TBK, which yield atomic and uni-compartmental body composition measurements ${ }^{(7)}$, the other techniques serve only to measure two or three compartments. To assess a four-compartment model, at least two methods for body composition assessment has to be used. Clearly, the most important method in this model is the one used to evaluate the mineral compartment ${ }^{(8)}$, which explains the success of methods using dual energy X-ray absorptiometry (DXA) ${ }^{(9-10)}$.

Of the methods for evaluating body composition, the traditional methods of hydrodensitometry, which is dependent on sex (i.e. bones are less dense in women which leads to an overestimation of body fat), age (i.e. the body fat of elderly patients suffering from osteoporosis may be overestimated), and the density of the musculoskeletal compartment (i.e. athletes tend to have denser bones and muscles than nonathletes, which may lead to an underestimation of body fat percentage), or skin-fold thickness will not be discussed in this review. Likewise, we will not comment on the much more sophisticated methods of IVNAA, tracer and gas dilution, and TBK, which are available only in specialized units and are not likely to be used by clinical nurses, or on methods, such as computed axial tomography and magnetic resonance imaging (MRI), which are too expensive to use routinely for body composition assessment.

\section{Methods used to assess body composition by nurses}

Bioimpedance analysis (BIA)

BIA systems usually are inexpensive, easily transportable and simple to operate. Therefore, nurses do not need to develop special skills and BIA is a useful supplement to anthropometry. In the BIA method, one or more frequencies are introduced via electrodes across a tissue bed, and the impedance (voltage drop) of the electrical flow is detected. Impedance is the opposition by tissue to the flow of electrical current and is the inverse of conductance. Impedance is determined primarily by the volume of fluid present in the electrical pathway. Fluids and water form relatively stable relationships with other components, and BIA methods often are designed to quantify FFM and, indirectly, fat (BW minus FFM)(11).

In standard whole-body BIA methods, the nurse places electrodes on the hand and foot; however, segmental measurements, such as the leg-to-leg system based on pressure-contact foot pad electrodes, are receiving increasing attention(11). An important limitation of BIA methods is that many underlying assumptions are made, some of which have not been adequately explored. Traditional BIA methods use a geometric model that assumes that the component of interest is homogeneous in composition. However, the typical electrical pathways used with BIA in humans fail to meet this condition. BIA methods, therefore, should be used only under appropriate and carefully controlled conditions $^{(11)}$.

Near-infrared interactance

Interactance systems also are inexpensive, easily transportable, and simple to operate by healthcare professionals. Infrared interactance, also known as nearinfrared interactance, is a method that has been proposed for the determination of human body composition. This technique is based on the principles of light absorption and reflection using near-infrared spectroscopy. When electromagnetic radiation strikes a material, energy is reflected, absorbed, or transmitted depending on the dispersive and absorptive properties of the material. The energy transmitted within the material is dispersed 
and reflected back to the emitter/receiver, transmitting information about the chemical composition of the material studied.

This technique was developed for the purpose of estimating the starch, protein, oil and water content of safflower seeds and oil. For estimates of human body composition, a computerized spectrophotometer with a simple, rapid monochromatic scanner and a fiber optic probe are used. The electromagnetic radiation used is in the wavelength range of 700 to $1100 \mathrm{~nm}$. First, the probe emits electromagnetic radiation in the selected body site, and then it receives the interactive energy, which is a combination of the reflected and dispersed energy that it conducts to the detector. The signal penetrates tissue to a depth of $1 \mathrm{~cm}$, and the composition is determined only at the measurement site. The interactance data are calculated by the instrument as the range of energy received from a target site relative to the energy received from a standard calibrator, which is a $1-\mathrm{cm}$ thick Teflon block.

As for the best site to examine subcutaneous fat with this method, in a comparative study, it was found that the data obtained by interactance in the subscapular and suprailiac regions and in the thigh did not correlate as well with the percentage of fat measured by deuterium dilution $^{(12)}$. However, there was a correlation between these methods for the values obtained from either the triceps or biceps regions, or the combined triceps and biceps. For this reason, authors postulated that the subcutaneous fat composition of the biceps region correlates closely with total body fat composition and hence, the midpoint of the biceps is the region were the device must be operated(12).

Although initially used in adults, near-infrared interactance has been validated for use in children and young people ${ }^{(13-14)}$ and in adults with different disease states $^{(15-16)}$

Dual energy X-ray absorptiometry

Dual energy X-ray absorptiometry was developed in a pioneering work with a single photon source ${ }^{(17)}$, after which a double photon source(18) was introduced and, finally, DXA ${ }^{(19)}$ was developed. The system's X-ray source produces a polychromatic photon spectrum. Exponential attenuation of the photons occurs as they pass through the subject's tissue. The attenuation characteristics are used to estimate the fraction of each component in the evaluated pixel, as follows: soft tissue plus bone mineral in pixels with bone and fat plus lean soft tissue in pixels with soft tissue alone. X-ray attenuation in human tissues at typical DXA energies is primarily related to the type and proportion of elements present and to the photon energy. Elements with a higher atomic number strongly attenuate photons.

DXA has been validated against biochemical determinations of fat content in animals ${ }^{(20-25)}$ and against a range of established techniques in humans, including hydrodensitometry and total body potassium ${ }^{(26-27)}$. DXA has been shown to be precise and accurate and to permit the quantification of fat and lean mass proportions in anatomically defined regions of interest ${ }^{(28-29)}$. DXA yields precise measurements of soft tissue and bone in specific regions and in the whole body. Body composition results obtained using this technique are not affected by changes in hydration. Therefore, DXA is considered to be a good method for evaluating the three-compartment model ( $B W=$ fat + bone minerals + lean soft tissue).

The relative expense of DXA compared with BIA and interactance, and the non-transportability of the instrument used detract from the merits of DXA as a method for measuring body composition. Although DXA is simple to perform, it is dependent on nurse skills and experience. Nurses should reassure the patient that the test is painless and non invasive and that it can usually be performed in less that 15 minutes. The nurse must ensure that the patient removes all jewelry from the body area to be examined.

\section{Conclusion}

Elevated body fat is related to health-related problems like atherosclerosis, high blood pressure, diabetes, lipidemia, obstructive pulmonary disease and osteoarthritis. Excessive leanness, as occurs in subjects with eating disorders, exercise addiction, and certain diseases, such as cystic fibrosis, can likewise result in life-threatening physiological dysfunction. In the light of the severity of the health problems linked with too much or too little body fat, it is no surprise that the assessment of body composition is a widespread and meaningful indicator used by nurses. As remarkable progress has been made in body composition measurements in the last several years, nurses need to keep their education up-to-date. Up-to-date knowledge allows a nurse to remain on the cutting edge of medical science. The first four levels of body composition can now be accurately measured by a clinical nurse, using systems that are inexpensive, easy to transport from one site to another, simple to operate, noninvasive and harmless. More sophisticated methods, such as dual energy X-ray 
absorptiometry, have the advantage of allowing male and female fat distribution to be evaluated, which aids in the assessment of cardiovascular risk.

\section{References}

1. Spivak CD. The specific gravity of the human body. Arch Intern Med. 1915;15628-44.

2. Cohn SH, Vaswani AN, Yasumura S, Yuen K, Ellis KJ. Improved models for determination of body fat by in vivo neutron activation. Am J Clin Nutr. 1984;40(2):255-9.

3. Fields DA, Goran MI. Body composition techniques and the four-compartment model in children. J Appl Physiol. 2000;89(2):613-20

4. Hoffer EC, Meador CK, Simpson DC. Correlation of whole-body impedance with total body water volume. J Appl Physiol. 1969;27(4):531-4.

5. Lee SY,Gallagher D. Assessment methods in human body composition. Curr Opin Clin Nutr Metab Care. 2008;11(5):566-72.

6. Ellis $\mathrm{KJ}$. Human body composition: in vivo methods. Physiol Rev. 2000;80(2):649-80.

7. Heymsfield SB, Wang Z, Baumgartner RN, Ross R. Human body composition: advances in models and methods. Annu Rev Nutr. 1997;17:527-58.

8. Christiansen C, Rodbro P, Nielsen CT. Bone mineral content and estimated total body calcium in normal children and adolescents. Scand J Clin Lab Invest. 1975;35(6):507-10.

9. Helba M, Binkovitz LA. Pediatric body composition analysis with dual-energy $\mathrm{X}$-ray absorptiometry. Pediatr Radiol. 2009;39(7):647-56.

10. Andreoli A, Scalzo G, Masala S, Tarantino U, Guglielmi G. Body composition assessment by dualenergy X-ray absorptiometry (DXA). Radiol Med. 2009;114(2):286-300.

11. Jaffrin MY, Morel H. Body fluid volumes measurements by impedance: A review of bioimpedance spectroscopy (BIS) and bioimpedance analysis (BIA) methods. Med Eng Phys. 2008;30(10):1257-69.

12. Conway JM, Norris KH, Bodwell CE. A new approach for the estimation of body composition: infrared interactance. Am J Clin Nutr. 1984;40(6):1123-30.

13. Nassis GP, Sidossis LS. Methods for assessing body composition, cardiovascular and metabolic function in children and adolescents: implications for exercise studies. Curr Opin Clin Nutr Metab Care. 2006;9(5):560-7.
14. Cassady SL, Nielsen DH, Janz KF, Wu YT, Cook JS, Hansen JR. Validity of near infrared body composition analysis in children and adolescents. Med Sci Sports Exerc. 1993;25(10):1185-91.

15. Oreopoulos A, Kalantar-Zadeh K, McAlister FA, Ezekowitz JA, Fonarow GC, Johnson JA, et al. Comparison of direct body composition assessment methods in patients with chronic heart failure. J Card Fail. 2010;16(11):867-72.

16. Noori N, Kovesdy CP, Dukkipati R, Kim Y, Duong $U$, Bross $R$, et al. Survival predictability of lean and fat mass in men and women undergoing maintenance hemodialysis. Am J Clin Nutr. 2010;92(5):1060-70.

17. Cameron JR,Sorenson J. Measurement of bone mineral in vivo: an improved method. Science. 1963;142230-2.

18. Leblanc AD, Evans HJ, Marsh C, Schneider V, Johnson PC, Jhingran SG. Precision of dual photon absorptiometry measurements. J Nucl Med. 1986;27(8):1362-5.

19. Kroger $H$, Kotaniemi A, Vainio P, Alhava E. Bone densitometry of the spine and femur in children by dual-energy x-ray absorptiometry. Bone Miner. $1992 ; 17(1): 75-85$.

20. Ammann P, Rizzoli R, Slosman D, Bonjour JP. Sequential and precise in vivo measurement of bone mineral density in rats using dual-energy $\mathrm{x}$-ray absorptiometry. J Bone Miner Res. 1992;7(3):311-6.

21. Svendsen OL, Haarbo J, Hassager C, Christiansen C. Accuracy of measurements of body composition by dual-energy $\mathrm{x}$-ray absorptiometry in vivo. Am J Clin Nutr. 1993;57(5):605-8.

22. Turner AS, Mallinckrodt $\mathrm{CH}$, Alvis MR, Bryant HU. Dual-energy $X$-ray absorptiometry in sheep: experiences with in vivo and ex vivo studies. Bone. 1995;17(4 Suppl):381S-7S

23. Nagy TR, Clair AL. Precision and accuracy of dualenergy X-ray absorptiometry for determining in vivo body composition of mice. Obes Res. 2000;8(5):392-8.

24. Zotti A, Rizzi C, Chiericato G, Bernardini D. Accuracy and precision of dual-energy x-ray absorptiometry for ex vivo determination of mineral content in turkey poult bones. Vet Radiol Ultrasound. 2003;44(1):49-52.

25. Swennen $Q$, Janssens GP, Geers R, Decuypere E, Buyse $\mathrm{J}$. Validation of dual-energy $\mathrm{x}$-ray absorptiometry for determining in vivo body composition of chickens. Poult Sci. 2004;83(8):1348-57. 
26. McClanahan BS, Stockton MB, Lanctot JQ, Relyea G, Klesges RC, Slawson DL, et al. Measurement of body composition in 8-10-year-old African-American girls: a comparison of dual-energy $X$-ray absorptiometry and foot-to-foot bioimpedance methods. Int J Pediatr Obes. 2009;4(4):389-96.

27. Kullberg J, Brandberg J, Angelhed JE, Frimmel $H_{\text {, }}$ Bergelin E, Strid L, et al. Whole-body adipose tissue analysis: comparison of MRI, CT and dual energy X-ray absorptiometry. Br J Radiol. 2009;82(974):123-30.

28. Rosenthall L, Falutz J. Estimation of total-body and regional soft tissue composition from DXA bone densitometry of the lumbar spine and hip. J Clin Densitom. 2010;13(3):263-6.

29. Covey MK, Berry JK, Hacker ED. Regional body composition: cross-calibration of DXA scannersQDR4500W and Discovery Wi. Obesity (Silver Spring). 2010;18(3):632-7. 